\title{
Some Problems Under the Federal Fair Labor Standards Act
}

\author{
Philip K. Verleger*
}

A ${ }_{\text {Fair Loyer who can prove a cause of action under the Federal }}$ Act guarantees him a dual right, the right to minimum wages ${ }^{2}$ and to time and a half for overtime, ${ }^{3}$ and if his employer denies him this right the employee may sue for twice the difference between the amount he has been paid and the amount required by statute, and in addition recover a reasonable attorney's fee. However, the protection of the Act is extended to only two groups of employees, those engaged in interstate or foreign commerce, and those engaged in production for such commerce, ${ }^{5}$ and the history of the Act as construed in the federal courts shows that there are some serious barriers in the path of the employee who attempts to prove that he falls within one of these two classes. And since the employee may bring his action in either state or federal courts, the federal decisions creating these difficulties raise a further problem, how far are these cases binding on state courts.

If he is to recover, the employee must first prove that his employment bears the necessary relation to interstate commerce. It is not yet clear who can sustain this burden; the applicability of the Act to some types of occupation has not yet been determined. There will probably always be borderline groups who cannot be certain whether they can or cannot claim the protection of the Act, but at present there are still gaps in our knowledge of the broad outline of its coverage. There are three main types of conduct affecting commerce: first, conduct affecting production for interstate commerce;

*LL.B., University of California, 1943; Lecturer in Commercial Law, University 'of California.

129 U.S. C. A. 201, et seq.

2 Ibid., $\$ 206$.

3 Ibid., $\$ 207$.

4 Ibid., $\$ 216$.

Ibid., $\$ \$ 206,207$; see $\$ 203 \mathrm{~b}$ and $\$ 203 \mathrm{j}$ for definitions of "commerce" and of "production". It should also be noted that certain specific groups of employees are excluded from the coverage of the act, who would otherwise be within the general categories of employees engaged in commerce, or in production for commerce. This article does not deal with the problems raised by these specific exclusions. 
second, conduct affecting transportation in interstate commerce; and third, conduct affecting interstate commerce at the receiving end -affecting the use of goods, and the demand for them at their ultimate destination. When Congress regulates conduct influencing interstate commerce at all these stages, probably it utilizes to the fullest possible extent the commerce power. It is settled that the Wages and Hours Act was not intended to do so much.

The Act expressly applies to employees engaged in production for commerce, including those "working . . . in any process or occupation necessary to ... production." In Kirschbaum v. Walling, the Supreme Court found this language broad enough to pernit the application of the Act to employees occupied in maintaining buildings in which production for interstate commerce was carried on. And in Warren-Bradshaw Drilling Co. v. Hall, ${ }^{9}$ it was held that where the oil produced in completed oil wells passed into interstate commerce, the men who drilled those wells were engaged in production for interstate commerce. This case raises a rather difficult problem. How can the person hiring the inen who drill the wells tell whether or not he need comply with the Act, since the destination of the oil will not be determined until after the wells are completed? Whatever be the answer to this question, it is apparent that Congress included nearly as many production employees by speaking of conduct "necessary to production" as it would had it spoken of conduct affecting commerce. If employees are "necessary to production" because their work involves the creation of facilities for production in interstate commerce, by the same token they should be engaged in work necessary to such production if they prepare the raw materials later used in production for interstate commerce. ${ }^{10}$ One function is as essential as the other.

${ }^{6}$ Kirschbaum v. Walling (1942) 316 U.S. 517, and cases cited infra note 14.

729 U.S. C. A. $\$ 203$ j.

${ }^{8}$ Supra note 6. A similar case is Walling v. Sondock, (C.C.A. 5 th, 1942). 132 F. (2d) 77 , holding that a night watchman at a plant engaged in production for interstate commerce came within the act. The case also serves to emphasize that it is the activity of the workman, not his employer, which determines the coverage of the act. The watchman was an employee of a local protective service. On this point, see also Swift \& Co. v. Wilkerson (C.C.A. 5th, 1942) 124 F. (2d) 176.

9 (1942) 317 U.S. 88.

10 Cases raising a problem somewhat like this are Consolidated Timber Co. v. Womack (C.C.A. 9th, 1942) 132 F. (2d) 101; and Hansbon v. Lagerstrom (C.C.A. 8th, 1943) $133 \mathrm{~F}$. (2d) 120 , holding cooks at lumber caunps engaged in production for interstate commerce are likewise engaged in such production. Although in McLeod v. Threl- 
In this connection some attention should be given a number of decisions in the lower federal courts and in some state courts. They are to the effect that if only a small part of an employer's business is in interstate commerce, the Act does not bimd him. ${ }^{11}$ They rely on language in N.L.R.B. v. Fainblatt, ${ }^{12}$ intimating that perhaps Congress will not ordinarily be regarded as having intended to regulate conduct, under the commerce power, when the effect of the conduct on commerce is so small as to come within the maxim de minimis. It is likely that this faith is in some degree misplaced, for the language relied on is to be found in close association with unequivocal assertions that the power to regulate conduct affecting interstate commerce is not ordinarily limited by the amount of the effect. ${ }^{13}$ The mention of the maxim may have been meant merely as a reference to situations in which the effect of acts on commerce would be indiscernible. Or it may have amounted to no more than an outbreak of the traditional judicial allergy to assertion without qualification, without hedging. The recent cases broadly construing "production for commerce" are a warning against the danger of taking too seriously this exception in favor of insignificance. For the effect on commerce of the activities of the building employees, the janitors who sweep out the plant in which production for commerce is carried on, could not have been large.

Employees whose activities affect commerce at the second stage, that of transportation, must rely on the clause of the Act that includes those who are "engaged in commerce" rather than that which speaks of those who are "engaged in production", defined as all whose activities are "necessary for production." And there is confusion in the cases delineating the meaning of the clause "engaged in production". It seems to be clear that it does not include, and therefore the Act excludes, employees whose activities affect goods which have

keld, infra note 14, a Supreme Court decision, the cook for the maintenance crew of an interstate carrier was held not to be "engaged in commerce", it is possible those cases are still correct, since the Court indicated that "production for commerce" is more broadly defined. In Hamlet Ice Co. v. Fleming (C.C.A.4th, 1942) 127 F. (2d) 165, it was held that production of ice for a railroad operating in interstate commerce was production for interstate commerce.

11 Goldberg v. Worman (S.D.Fla. 1941) 37 Fer. Supp. 778; Gerdert v. Certified Poultry \& Egg Co. (S.D.Fla. 1941) 38 Fed. Supp. 964; Samuels v. Houston (S.D.Ga. 1942) 46 Fed. Supp. 364; Lamb v. Quality Baking Co. (Tenn. C. A. Aug. 10, 1940) 3 Lab. Cas. 60,084; Whitson v. Wexler (Tenn. Ch. Jan. 10, 1941) 3 Lab. Cas. 60,859.

12 (1939) 306 U.S. 601.

13 Ibid. at 607 . 
passed out of interstate transportation. ${ }^{14}$ But it is hard to say how closely an activity need be concerned with transportation before the acting employee can recover under the Act. In Overstreet $v$. North Shore Corporation ${ }^{15}$ the Supreme Court held that employees engaged in maintaiming a toll road and bridge used for interstate commerce are within the Act. But more recently, in McLeod v. Threlkeld, the Court held that the cook for such a maintenance crew does not have the rights given by the Act. ${ }^{16}$ And by way of additional contrast, the Court previously had held that a rate clerk, employed by an interstate carrier, is within the Act. ${ }^{17}$ No satisfactory ground of distinction appears to exist between these cases. While it may be conceded that the activities of the maintenance crew are a little more closely associated with commerce than those of the cook for the crew, between the position of the cook and the rate clerk there appears to be less difference. True, if there were no rates, presumably there would be no commerce, but on the other hand, if there were no cook, presumably there would be no crew, and if there were no crew, there would also be no commerce. While it might be physically possible to have the commerce without rates, it is hard to see how there could be commerce without the cook. Since there were four dissenters in the $M c L e o d$ case, ${ }^{18}$ it may be that this case marks one of the limits to the restriction of the scope of the coverage of the Act; nevertheless, it is a little hard to tell where this limit has been placed.

One of the more difficult problems in construing the Act is to tell at what point goods have passed out of interstate transportation, so that thereafter employees handling them will not be protected by the Act. The Supreme Court dealt most extensively with that problem in Walling v. Jacksonville Paper Co. ${ }^{10}$ involving a paper company which operated mills from which goods were shipped in interstate commerce to warehouses, and thence to the ultimate customers, who as a rule were located in the same state as the warehouse from which their goods arrived. Three types of merchandise were transported. Some goods were shipped from the mill to the warehouse on the order of a customer. These materials were held to remain in interstate

14 Higgins v. Carr Bros. (Jan. 1943) 318 U.S. 658; Walling v. Jacksonville Paper Co. (Jan. 1943) 63 S. Ct. 332, 87 L. ed. Adv. Ops. 393; McLeod v. Threlkeld (June, 1943) 63 S. Ct. 1248, 87 L. ed. Adv. Ops. 1154.

15 (Feb., 1943) 318 U.S. 125.

16 McLeod v. Threlkeld, supra note 14.

17 Overnight Transport Co. v. Missel (1942) 316 U.S. 572.

18 Black, Douglas, Murphy and Rutledge, JJ.

19 Supra note 14. 
commerce until delivered to the customer-the warehouse was treated merely as a way station on the lime of transportation. Second, some materials were shipped from the mill to the warehouse im anticipation of the demands of particular customers; for example, there was paper which though it had not been ordered, was printed at the mill with the name of the customer. These goods were treated in the same manner as those transported on order from the customer. Employees handlimg either the goods on order or the goods shipped in anticipation of particular orders, were held to be engaged in interstate commerce. Third, the remainder of the products involved were shipped from the mill to the warehouse merely in anticipation of demands from the mass of the customers of the business. As to these, it was said that once they reached the warehouse, they had not been shown to be different from "goods acquired and held by a local merchant for local disposition". ${ }^{20}$ Employees who handled these goods after they reached the warehouse were not engaged in interstate commerce. Apparently the test applied was whether or not the goods with which the employee was concerned had reached, for a time at least, the intended end of their interstate journey. This is not a test of great precision, but it is hard to see how there could be a more meticulous standard. In this connection it should be noted that the Supreme Court has warned that cases concerned with various other applications of the commerce power by the state and federal governments are not regarded as shedding much light on the construction of the Act. ${ }^{21}$

It was indicated above that practically all employees whose activities substantially affect production for interstate or foreign commerce are covered by the Act. That statement was too broad. Kirschbaum v. Walling and Warren-Bradshaw Drilling Co. v. Hall, were

20 Walling v. Jacksonville Paper Co., supra note 14. Somewhat similar results were reached in Jax Beer Co. v. Redfern (C.C.A. 5th, 1941) 124 F. (2d) 172; Walling v. Goldblatt Bros. (C.C.A. 7th, 1942) 128 F. (2d) 778. The Jacksonville Paper Co. case was distinguished in Walling v. American Stores Co. (C.C.A.3d, Feb. 1943) 133 F. (2d) 840 , holding that all of the warehouse employees of a chain store system were covered by the act. Goods were stored at the warehouses until needed at retail units. The theory used was that the retail units were part of the same system as the warehouses, and the warehouses were mere conveniences in getting goods from out of state to the retail units. The distinction is a close one, but this is a borderline area.

21 Kirschbaum v. Walling, supra note 6; Walling v. Jacksonville Paper Co., supra note 14. Yet in Overstreet v. North Shore Corporation, supra note 15, the court indicated that in the construction of the phrase "engaged in commerce" cases under the Federal Employers' Liability Act, 45 U.S.C.A. (1943) \$51, et seq., might be given some weight. 
cases involving employees whose activities had a discernible function in the mechanical process of production, that is, they created the necessary facilities or were engaged in maintaining them. These cases do not decide whether the Act was intended to regulate the wages of employees whose activities affect interstate commerce through a purely economic chain of causation. In one respect at least, it is clear that the Act does not include such employees. In an economic sense, the activities of employees who engage in dispensing goods to the ultimate consumer are essential to the production of those goods. If there were no such distribution, there would be no production. Yet it is thoroughly settled that employees engaged in the process of local distribution are not employed "in commerce", or in "production for commerce" within the meaning of the Act, if there has been a previous break in the interstate transit of the goods distributed. And so, it is sometimes said that the phrases of the Act are intended to exclude business that is primarily "local". ${ }^{22}$ Because the Act expressly includes employees "engaged in production for commerce," and "engaged in commerce", whereas there is no general inclusion of employees whose activities affect commerce, those employees whose activities affect commerce only at the end closest to the consumer are excluded, and the economic effect on commerce of retailing, local wholesaling and the like, does not suffice to give employees engaged therein the benefit of the Act.

Nevertheless, it is not hard to describe a situation in which, because of the economic effect of employee activities, a plausible case may be made for their inclusion in the coverage of the Act. There are undoubtedly many plants manufacturing goods for consumption partly in the state where the plant is located and partly for export elsewhere. Both markets may be needed if the business is to remain solvent. If so, in an economic sense, the activities of both groups of employees are necessary for production for interstate commerce. Are the employees who produce goods consumed solely in the state where produced protected by the Act? ${ }^{23}$ The same question may be asked of employees engaged in transportation. As to them, however, it may have been answered. In the Jacksonville Paper Mill case the Court was concerned with the employees of a plant doing a mixed inter-

22 Higgins v. Carr Bros. Co., Walling v. Jacksonville Paper Co., both supra note 14.

23 United States v. Wrigbtwood Dairy Co. (1942) 315 U. S. 110, is a case of regulation under the commerce power, entirely because of the economic relationship of a business to commerce; the relationship was that the unit regulated was a competitor of units engaged in commerce. 
and-intrastate business. Certainly the welfare of the intrastate business must have had a substantial economic connection with the welfare of the entire business, and with the continuation of the interstate transportation. Nevertheless, the employees concerned with intrastate transportation were held not to be covered by the Act. It may be questioned whether this case establishes finally any rule that an economic connection with transportation is insufficient to bring an einployee within the scope of the Act. In Overnight Motor Transport v. Missel, ${ }^{24}$ the Supreme Court held that a rate clerk einployed by an interstate carrier was engaged in commerce. It is hard to see what connection he had with such commerce, except that his activities were useful to the financial side of the business conducting the commerce. So long as money was to be made from transportation, he may have been essential. If no money was inade, there would have been no transportation. But it may likewise be true that if no money be made from the intrastate side of a business, the interstate transportation in which it is engaged will cease. It is impossible, however, to determine how much significance to attach to the decision, since its conclusion is substantially contradicted by that reached in $\mathrm{Mc}$ Leod v. Threlkeld.

An employee who is engaged in an activity connected with production, as distinguished from transportation, has a stronger case when he seeks to invoke the sanctions of the Act. The Act specifically defines employment in production for commerce as including any employment necessary for such production. ${ }^{25}$ Thus, if an employee was engaged in producing goods for intrastate commerce, and the continuation of such production was necessary if the business employing him was to remain a solvent and active producer for interstate commerce, he could argue that his employment was necessary for production for interstate commerce. Employment "in commerce" is not so broadly defined, ${ }^{26}$ and the Court was construing employment "in commerce" in the Jacksonville case. It may yet be held that the economic interdependence of the inter- and intrastate production in particular plants will result in making the benefits of the Act available to all of the employees hired in such plants.

The result of the Jacksonville Paper Co. decision is that some

24 Supra note 17.

2529 U.S.C.A. $\$ 203$ j.

26 The fact that the phrase, engaged in commerce, is more narrowly defined is expressly relied on in Johnson v. Dallas Downtown Development Co. (C.C.A. 5th, 1942) 132 F. (2d) 287. See also McLeod v. Threlkeld, supra note 14. 
employees at a given plant may be entitled to receive the minimum wages and overtime wages required by the Act, and others may not. An additional consequence is that an employee may pass in and out of the coverage of the Act from week to week or from day to day, depending on the ultimate destination of the particular product with which he is concerned. ${ }^{27}$ In this situation, the basic unit is the work week; the statutory minimum must be paid for any week in which an employee is engaged in interstate production or transportation; likewise, time and a half must be paid for overtime, but no such requirement is made for the weeks in which the employee is concerned solely with intrastate business. ${ }^{28}$ When a given plant handles a mixture of inter- and intrastate business it is likely to be difficult for any employee to prove which he is concerned with, and even more difficult for him to prove how much of his time is spent on each type of commerce if he works on both. If his employment is in production, he may have no way of telling which type he is associated with, for the ultimate destmation of the goods may not be determined until completed. If the destination of each job has been previously settled, it is likely that his employer will know of that destination, unlikely that the employee will. If the destinations of the jobs are not settled until the work has been completed, it is likely that all employees have something to do with interstate commerce, and therefore all should be entitled to receive the benefits of the Act. Therefore, it seems reasonable to conclude that the employee proves a prima facie case by showing that his employer is partially concerned with producing for, or transporting goods in interstate commerce, and that the employer must prove that the duties of his men are segregated, if such is the fact. This seems to have been the construction placed on the Act by the Administrator of the Wages and Hours Division. ${ }^{20}$ However, the cases almost unanimously reach the opposite conclusion, and require the employee to prove that his duties have the requisite relation to commerce, ${ }^{30}$ and also require him to prove the

27 Walling v. Jacksonville Paper Co., supra note 14, and cases cited supra note 20.

28 Fair Labor Standards Act, Interpretative Bulletin No. 5, Wages \& Hours Release No. R. 113, 2 C. C. H. Lab. Law Serv.' $\{32,204$.

20 Ibid.

30 Super-Cold Southwest Co. v. McBride (C.C.A.5th, 1942) 124 F. (2d) 90; Klotz v. Ippolito (S.D. Tex. 1941) 40 Fed. Supp. 422; Owin v. Liquid Carbonic Corp. (S.D. Tex. 1941) 42 Fed. Supp. 774; Silgaro v. Port Compress Co. (S.D. Tex. 1942) 45 Fed. Supp. 88; Cullum v. Stevens (N.D. Tex. 1942) 46 Fed. Supp. 73; Moore v. Perkins Dry Goods Co. (N.D. Tex., 1942) 5 Lab. Cas. 62,783; Monk v. Continental Baking Co. (N.D. Tex., 1942) 5 Lab. Cas, 62,824. 
amount of his time spent in such an occupation, if his duties are inixed, and some of his labors are concerned with intrastate commerce. ${ }^{31}$ These decisions are consistent with. the rule that plaintiff ordinarily has the burden of proving matters which are part of his cause of action, ${ }^{32}$ but they do place a considerable burden on hin.

It is not inconceivable that a state court dealing with a cause of action under the Fair Labor Standards Act would feel that plaintiff deserves more assistance than these cases give him. Such a court might be of the opinion that the employer, not the employee, would probably have in his hands nost of the evidence necessary to determine whether there existed in his plant a division of labor between inter- and intrastate production or transportation, and whether a particular employee worked in either or both, and should be required to produce this evidence. To attain this object, it imght be logical to hold that once the employee proves that his employer is partly engaged in production for interstate commerce or transportation, a presumption arises that the employee also is so engaged. Assuming that a state court was so inclined, the question would be, was it free to utilize this device? The chief argument for an affirmative answer is probably, that a state court certainly has the power to decide questions of procedure in state courts.

There are good reasons for believing that this generalization does not provide an adequate answer to the question. It is a cominonplace that state courts must follow federal decisions to a substantial extent in determining rights under federal $\mathrm{law}^{33}$ It does not necessarily follow that this obligation ceases to exist merely because the federal decisions relate to what is traditionally regarded as "procedure" rather than "substance". ${ }^{34}$ It has been held that in determining rights

$\mathbf{3 1}$ Cases cited $i b i d$.

32 Likewise many cases have heen strict in the amount of proof required of the amount of overtime. Jax Beer Co. v. Redfern, supra note 20; Johnson v. Dierks Lumber \& Coal Co. (C.C.A. sth, 1942) 130 F. (2d) 115 ; Wilkinson v. Noland Co. (E.D. Va., 1941) 40 Fed. Supp. 1009 ; Mortenson v. Western Light \& Tel. Co. (S.D. Ia., 1941) 42 Fed. Supp. 319.

33 New York Cent. R. R. v. F.H. Buck Co. (1935) 2 Cal. (2d) 384, 41 P. (2d) 547; Penn. R. R. Co. v. Midstate Co. (Nov. 1942) 21 A. C. 255, 131 P. (2d) 544. The rule that by legislating within a given area, Congress occupies the field, thereby depriving state law of any effect even though the state law covers details untouched by congressional enactment, so that "federal common law" must be used to fill the gaps, gives a very broad scope to such decisions. See (1942) 30 CaLIF. L. REv. 568.

34 Cook, "Substance" and "Procedure" in the Conflict of Laws (1932) 42 YALE L. J. 333; Tunks, Categorization and Federalism: "Substance" and "Procedure" after Erie Railroad v. Tompkins (1939) 34 Irc. L. REv. 271. 
under state law, federal courts are bound by state decisions governing the burden of proof $;^{35}$ the effects of a presumption; ${ }^{36}$ the availability of the doctrine of res ipsa loquitur; ${ }^{37}$ and even the admissibility of evidence. ${ }^{38}$ The problem of determining what state decisions federal courts must follow seems to have been approached on the theory that all state rules seriously affecting the probable outcome of a lawsuit are controlling. ${ }^{39}$ The same test appears to describe the appropriate limit to the freedom of a state court to follow its own predilections in fields of federal law. It is undesirable to permit the parties to procure differences in result by selecting different forums whether state law or federal law governs the case. ${ }^{40}$

This same problem was met in decisions construing the Federal Employers' Liability Act, ${ }^{41}$ which, like the Fair Labor Standards Act, places upon state courts the duty of adjudicating rights under federal law. It has long been established that in suits under this Act, state courts must apply the federal rule on the burden of proof of contributory negligence; ${ }^{42}$ likewise that they are bound by federal decisions determining the availability of a directed verdict. ${ }^{43} \mathrm{It}$ therefore seems probable that in applying the Fair Labor Standards Act, state courts are not free to give plaintiff the benefit of a presumption that he is employed in commerce, so long as the federal cases are so strict in requiring that he fully prove such employment himself. ${ }^{44}$

35 Cities Service Oil Co. v. Dunlap (1939) 308 U. S. 208; Sampson v. Channell (C.C.A. 1st, 1940) 110 F. (2d) 754; Equitable Life Assur. Soc. v. MacDonald (C.C.A. 9th, 1938) 96 F. (2d) 437; Francis v. Humphrey (E.D. Ill., 1938) 25 Fed. Supp. 1; Schopp v. Muller Dairies (E.D. N.Y., 1938) 25 Fed. Supp. 50. See Notes (1939) 37 Mich. L. Rev. 1349; (1940) 8 Geo. WASE. L. Rev. 860; (1939) 6 U. of CHI. L. Rev. 510; (1939) 24 Iowa L. REv. 609.

${ }^{36}$ Dismang v. Western Union Telegraph Co. (N.D. Okla., 1938) 24 Fed. Supp. 782. 37 Coca-Cola Bottling Co. v. Munn (C.C.A. 4th, 1938) 99 F. (2d) 190; Hagan \& Cushing Co. v. Washington Water Power Có. (C.C.A. 9th, 1938) 99 F. (2d) 614. 38 Coca-Cola Bottling Co. v. Munn, ibid.; Pollard v. Nicholls (C.C.A. 5th, 1938) 99 F. (2d) 955 ; Chicago G. W. R. Co. v. Robinson (C.C.A. 8th, 1939) 101 F. (2d) 994. See Dye, Development of the Doctrine of Erie Railroad v. Tompkins (1940) 5 Mo. L. REv. 193.

${ }^{39}$ See Tunks, loc. cit. supra note 34; Note (1938) 38 CoL. L. Rev. 1472.

40 That this could occur was the objection repeatedly made to the rule of Swift v. Tyson (1842) 41 U.S. 1, finally overruled in Erie Railroad v. Tompkins (1938) 304 U. S. 64. See McCornick \& Hewins, The Collapse of "General" Law in the Federal Courts (1938) 33 IrL. L. Rev. 126.

41 Supra note 21.

42 Central Vermont Ry. Co. v. White (1915) 238 U. S. 507.

43 Western Atlantic R. R. Co. v. Hughes (1928) 278 U. S. 496.

4 In L. \& N. R. Co. v. Grant (1928) $223 \mathrm{Ky} .39,2$ S. W. (2d) 1063 , it was held 
The conclusion that federal decisions must be followed may not determine the result in many cases, for there are many federal courts, and it is likely that they will not be unanimous in their convictions. The question will then arise, what decisions should be followed? If the question is settled within the federal courts of the ninth circuit, the conclusion of those courts should be binding on a court of the State of California, whether or not in accord with the weight of federal authority, for the decisions of the ninth circuit in effect determine the federal law for the areas within it, until the Supreme Court intervenes. The conclusion that the California courts were free to follow the decisions of other circuits would revive the possibility of obtaining a different result through the selection by the litigant of a state instead of a federal court as a forum. And presumably, just as federal courts are bound to follow the decisions of lower state courts, if no others are available, ${ }^{45}$ so state courts would be bound to follow the decisions of district courts if the Supreme Court or circuit court of appeals had not passed on the question. If there were no pertinent decisions by any of the federal courts of the ninth circuit, then presumably the courts of California would be bound by the decisions of the courts of other circuits. Such decisions have the effect, to some extent, of making law for all circuits, for in the absence of a decision by its own circuit court, ordinarily a district court will follow the decision of a court of appeals in another circuit ${ }^{46}$ and in general, federal courts give quite a bit of weight to the decisions of federal courts of like authority in other circuits. ${ }^{47}$ It is not often that a state court will face a problem under the Act without even the decision of a district court in another circuit to guide it. The decisions of state courts are not likely to be very important in formulating either the substantive or procedural rules governing the application of the Act.

that the state court was bound to follow federal cases on res ipsa loquitur in suits under the Federal Employers' Liability Act. In Barnet v. N. Y. C. \& H. R. R. R. Co. (1918) 222 N.Y. 195,118 N.E. 625 , it was held that the state court was bound to apply the federal rule on burden of proof in suits under another federal statute, the Carmack Act, 49 U. S. C. A. \$20. However, in Showalter v. Western Pacific R. R. Co. (1940) 16 Cal. (2d) 460,106 P. (2d) 895 , the state rule as to admissibility of evidence was applied to a suit under the Federal Employers' Liability Act. But $c f$. C. M. \& St. P. Ry. v. Coogan (1925) 271 U.S. 472, and authorities collected, supra note 35.

45 Six Companies v. Highway Dist. (1940) 311 U.S. 180; Note (1941) 29 CAL. L. REv. 380.

46 Pitzer Transfer Corp. v. Norfolk \& W. Ry. Co. (D. Md., 1935) 10 Fed. Supp. 436.

47 Bright v. Arkansas (C.C.A., 8th, 1918) 249 Fed. 950; New Amsterdam Casualty Co. v. Iowa State Bank (C.C.A. 8th, 1921) 277 Fed. 713; Ball v. Chapman (C.C.A. 7th, 1924) 1 F. (2d) 895; United States ex. rel. Hughes v. Gault (S.D. Ia., 1925) 13 F. (2d) 225; Arlac Dry Stencil Corp. v. A. B. Dick Co. (C.C.A. 3d, 1931) 46 F. (2d) 899. 